\title{
CONFIRMATION OF THE PRESENCE OF PACHYPAPPA WARSHAVENSIS (NASONOV, 1894) [HEMPITERA APHIDIDAE] IN THE IBERIAN PENINSULA
}

\author{
${ }^{a}$ Instituto de Biología Integrativa de Sistemas (I'SysBio). Universidad de Valencia - CSIC. Centro Mixto Universidad de \\ Valencia-CSIC (Paterna, Valencia). Spain. \\ Corresponding Author: Alice Casiraghi; ali.casi@outlook.it
}

Casiraghi A., Martínez-Torres D., Pérez Hidalgo N. - Confirmation of the presence of Pachypappa warshavensis (Nasonov, 1894) [Hempitera Aphididae] in the Iberian Peninsula.

The aphid Pachypappa warshavensis (Nasonov) (Aphididae: Eriosomatinae: Pemphigini) on its primary host Populus alba L. is properly confirmed in the Iberian Peninsula. The species was initially cited as Asiphum varsoviensis (Mordvilko, 1835) in Spain, but the absence of specimens in the entomological collections, as well as the alleged limited distribution to the countries of Northern and Eastern Europe, made it removed from the list of the Ibero-Balearic aphids P. warshavensis is a Palaearctic species that is widely distributed in Europe (Belarus, Germany, Hungary, Poland, Romania, Serbia, Spain, Sweden and Ukraine) and Central Asia (Kazakhstan). The identification based on morphological and molecular characters (COI) has been confirmed and the fundatrix and its winged fundatrigenia are described. In addition, phylogenetic relationships based on COI sequences of $P$. warshavensis with other Pachypappa species available in the databases are presented.

Key Words: Aphids, COI, Populus alba, faunistic studies, Eriosomatinae, Pemphigini.

\section{INTRODUCTION}

The genus Pachypappa Koch 1856 corresponds to a little aphid taxon from the Pemphigini tribe (Hemiptera: Aphididae: Eriosomatinae), that host alternates between species of Populus L. (the primary host) and different secondary hosts, not always known, but frequently being different species of Picea Dietrich (five species) or Salix L. (two species) (PIKE et $a l ., 2012$; BLACKMAN and EASTOP, 2019).

Pachypappa groups 13 species with Holarctic distribution (FAVRet, 2019). Of these, three are Nearctic (Canada and United States), and the rest are widely distributed in the Palaearctic region, from Britain to Japan, or only in a part of it (BLACKMAN and EASTOP, 2019).

Currently, six species are present in several countries of Northern and Central Europe: P. marsupialis Koch 1856, $P$. myrtilli Börner 1950 (only in Germany), P. populi (Linnaeus 1758), P. tremulae (Linnaeus 1761), P. vesicalis Koch 1856 and $P$. warshavensis (Nasonov 1894) (NIETO NAFríA et al., 2011; BLACKMAN and EASTOP, 2019). The genus is characterized by large fundatrices without waxy plates and alatae spring migrants always having wax plates and forewings generally with a once-branched medial vein (BLACKMAN and EASTOP, 2019).

Like most species of Pemphigini and other Eriosomatinae, their full (holocyclic) life cycles are rather complex and their ability to develop paracycles on subterranean parts of their secondary hosts makes their taxonomy problematic in some species. However, nowadays some of these taxonomic problems can be solved using molecular studies (PIKE et al., 2012).

In early-June 2018 typical pseudogalls made by Pachypappa aphid colonies were found on several white poplars in the city of León (Fig. I). A detailed study of the fundatrix, and alatae viviparous females revealed that they belonged to the aphid genus Pachypappa, and more specifically to Pachypappa warshavensis (Nasonov), a species that was mentioned for the first time in the Iberian Peninsula by Gómez-MENOR and Nieto (1977) as Asiphum varsoviensis (Mordvilko, 1835), currently synonym of $P$. warshavensis (Nasonov, 1894). However, the absence of specimens of this sample in the entomological collections that could confirm it, the null results after the efforts made for its location, as well as its limited distribution to the countries of northern and eastern Europe, made think to Pérez Hidalgo and Nieto Nafría (2003a) that this species was not present in Spain and that it could be an identification error

Our records, therefore confirm definitively the presence of this species of Pemphigini in the Iberian Peninsula.

\section{MATERIALS AND METHODS}

\section{Material COlLeCted}

Aphids were collected on 4-vi-2018 from various plants of Populus alba L. located between coordinates 42.610522, -5.590680 and $42.605037,-5.586273$, in a green area on the left bank of the Bernesga river, along a path in the city of León. Half of the sampled aphids were put in $100 \%$ ethanol for molecular analysis and the other half in $70 \%$ ethanol solution for morphological studies. The aphids (sample references: 1850 and 1779) and the DNA were deposited in the aphidological collection of the Institute for Integrative Systems Biology (Mixt Center of University of Valencia and CSIC).

\section{MORPHOLOGICAL STUDY}

Subsequently, the individuals in $70 \%$ ethanol were used to mount microscope slides following the methodology 

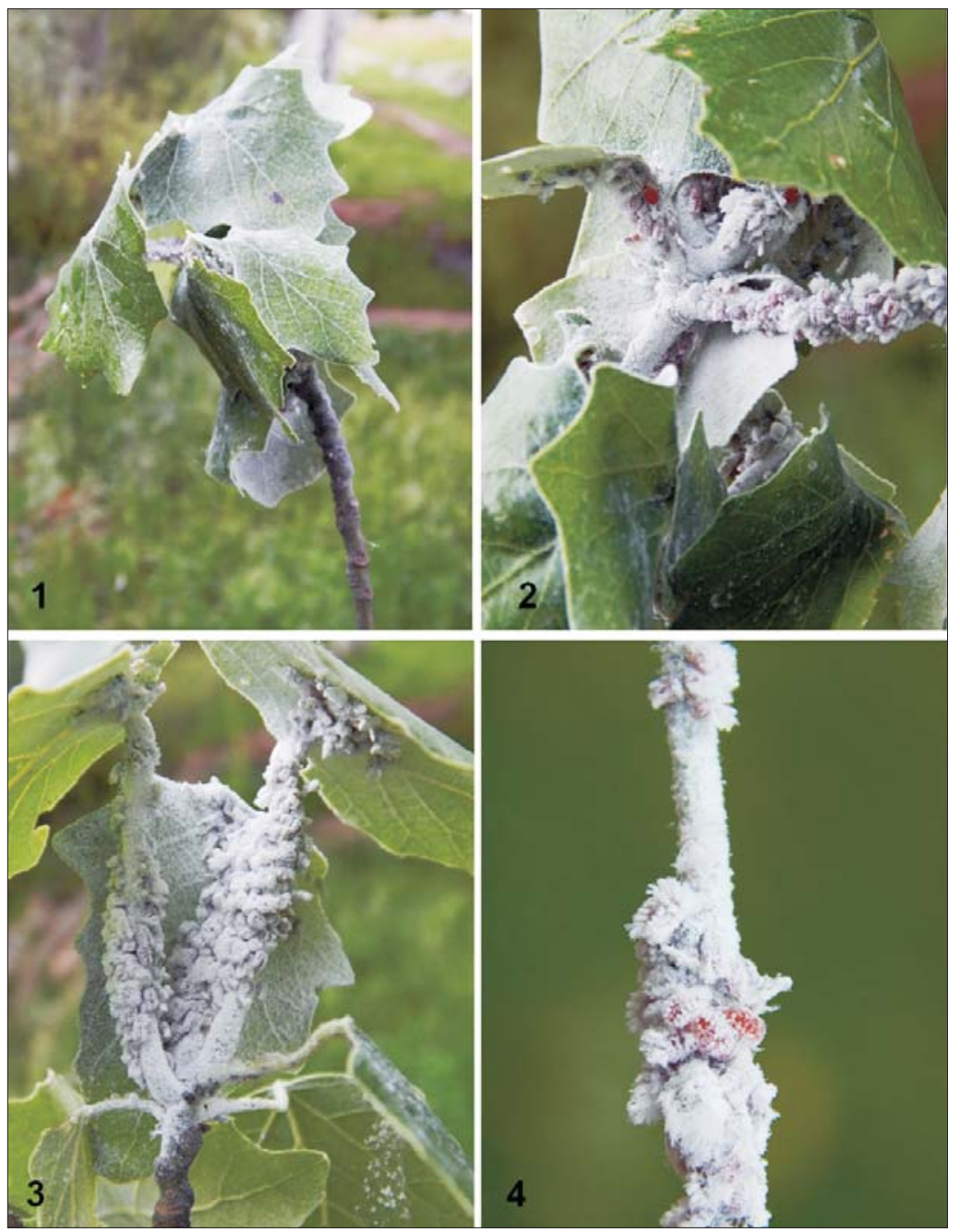

Fig. I - Several colonies of Pachypappa warshavensis (Nasonov) on Populus alba.

described by Nieto Nafría and Mier Durante (1998). Identification at the species-level was carried out using quantitative and qualitative characters, following the identification keys of HEIE (1980) and BLACKMAN and EASTOP (2019). A camera lucida fitted to the microscope was used for the drawings and the microphotographs were taken with a Leica DC digital camera with IM 1000 version 1.10 software.

\section{DNA EXTRACTION AND PCR AMPLIFICATION}

The specimens conserved in $100 \%$ ethanol were used in DNA extraction following the HotSHOT method (Hot Sodium Hydroxide and Tris) (TRUETT et al., 2000). In a second step, a $710 \mathrm{bp}$ fragment of the 5' region of the mitochondrial cytochrome c oxidase subunit 1 (COI) was amplified using primers LCO1490 and HCO2198 (FOLMER et al., 1994). $3 \mu \mathrm{l}$ of the extracted DNA was used for every amplification. PCR conditions were as follows: $94^{\circ} \mathrm{C}$ for 1 min; 35 cycles of $94^{\circ} \mathrm{C}$ for $30 \mathrm{~s}, 48^{\circ} \mathrm{C}$ for 1 min and $68^{\circ} \mathrm{C}$ for $1 \mathrm{~min}$; a final extension step of $7 \mathrm{~min}$ at $68^{\circ} \mathrm{C}$ was included after cycling.

\section{SEQUENCING AND ANALYSIS OF DNA SEQUENCES}

PCR products were purified by ammonium precipitation and reconstituted in $10 \mu \mathrm{L}$ of LTE buffer $(10 \mathrm{mM}$ Tris, $0,1 \mathrm{mM}$ EDTA). Sequencing of the amplified fragments was done using PCR primers and conducted using the Big Dye Terminator v3.1 Cycle Sequencing Kit (Applied Biosystems) following the manufacturer's instructions.
Samples were loaded onto an ABI 3700 automated sequencer. Sequences corresponding to each sample were assembled using Staden package v2.0.0 (STADEN et al., 1998). Multiple alignments were carried out with Clustal X v1.81 (THOMPSON et al., 2002) with gap opening and gap extension penalties of, respectively, 10.0 and 0.2 , and then manually revised. MEGA7 (KUMAR et al., 2016) was used to align sequences and to do the phylogenetic analysis. The Neighbor-joining algorithm on Kimura 2-parameters distances was used to build a phylogenetic tree including several Pachypappa sequences available at NCBI (accession numbers MG508635.1, MF830952.1, KR0 29847.1 and GU679671.1) along with the sequence of $P$. warshavensis here reported. Node support was obtained after 500 bootstrap replicates. The sequence of the species Mordwilkoja vagabunda (Walsh 1863) was used as outgroup (accession number KR043679.1).

\section{RESULTS}

\section{MORPHOLOGICAL DATA}

The analysis of qualitative and quantitative (metric and meristic) characters of the specimens available (one fundatrix and hundreds of fundatrigeniae viviparous females) confirmed that they belong to the genus Pachypappa, because the fundatrix lacks waxy plates and the fundatrigeniae viviparous females have oval primary rhinaria surrounded by distinct rings of shorts hairs and small 
siphuncular pores, with a diameter shorter than 2.3 times the articular diameter of antennal segment III (HEIE, 1980). The association with Populus alba and the presence of secondary sensoria with thick sclerotic rims on the distal half of the antennal segment III (Fig. II, 1), among other characters, identified it as $P$. warshavensis (Nasonov) (HeIE, 1980; BLACKMAN and EASTOP, 2019).

The only one fundatrix caught is large $(4.34 \mathrm{~mm})$ but with short appendages (antenna of $0.6 \mathrm{~mm}$ and 0.14 times the body length and hind tibia $0.62 \mathrm{~mm}$ and 0.14 times the body length). In life, it is reddish-brown and lacks waxy plates and siphunculi. The antenna (Figs. II, 2; III, 2) has five segments without secondary sensoria and the antennal segment III is 0.64 times the rest of antennal flagellum and the terminal process is 0.09 times the part basal of the last antennal segment $(D)$. The rostrum is around $0.77 \mathrm{~mm}$ and the apical rostral segment is $0.19 \mathrm{~mm}, 1.32$ times its basal width and 0.9 times the segment of the hind tarsus. The cauda is rounded and short $(0.09 \mathrm{~mm}$ and 0.38 times its width). The anal plate has a large number of setae (around 35 ) and the genital plate have 14 on the anterior part and 25 on posterior marge (Fig. III, 3). The setae on the vertex is around $0.09 \mathrm{~mm}$ and 2.73 times the articular diameter of antennal segment III. The spinal setae on abdominal segment III is $0.036 \mathrm{~mm}$ and the marginal of the same segment is $0.042 \mathrm{~mm}$ ( 1.09 and 1.27 times $D$, respectively) and the setae on abdominal segment VIII is $0.093 \mathrm{~mm}$ and 2.82 times $D$.

The alate fundatrigenia females (measurements based on 20 specimens) are large (2.9-3.84 $\mathrm{mm}$ ), with wings of $3.69 \mathrm{~mm}$ and 2.88 times its maximal width and with the medial vein variable: unbranched $(14 \%$ of 100 studied specimens) (Fig. IV, 1) or with a fork, short (7\%) (Fig. IV, 2) or quite big (75\%) (Fig. IV, 3), even different medial vein phenotypes can appear in the same individual. Colour in life

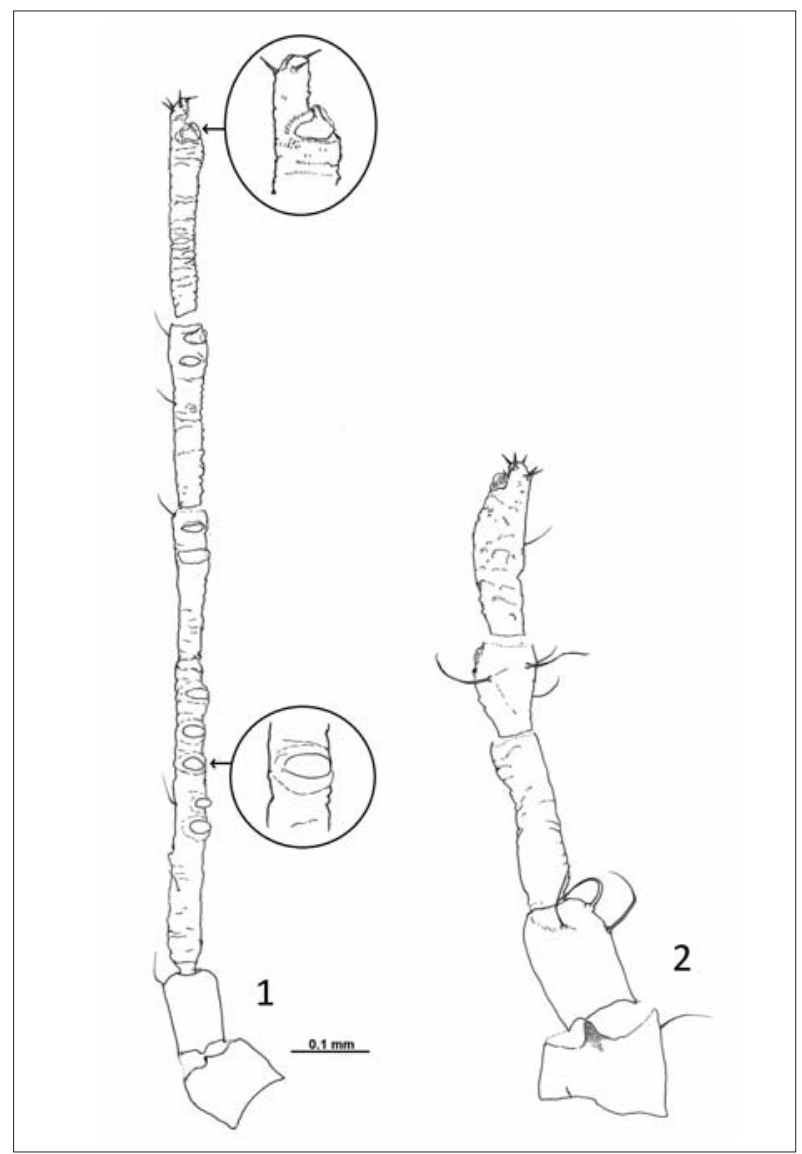

Fig. II - Antenna of the fundatrigenia alata (1), with detail of secondary sensoria on antennal segment III and primary sensoria of the last antennal segment, and antenna of the fundatrix (2) of Pachypappa warshavensis (Nasonov).

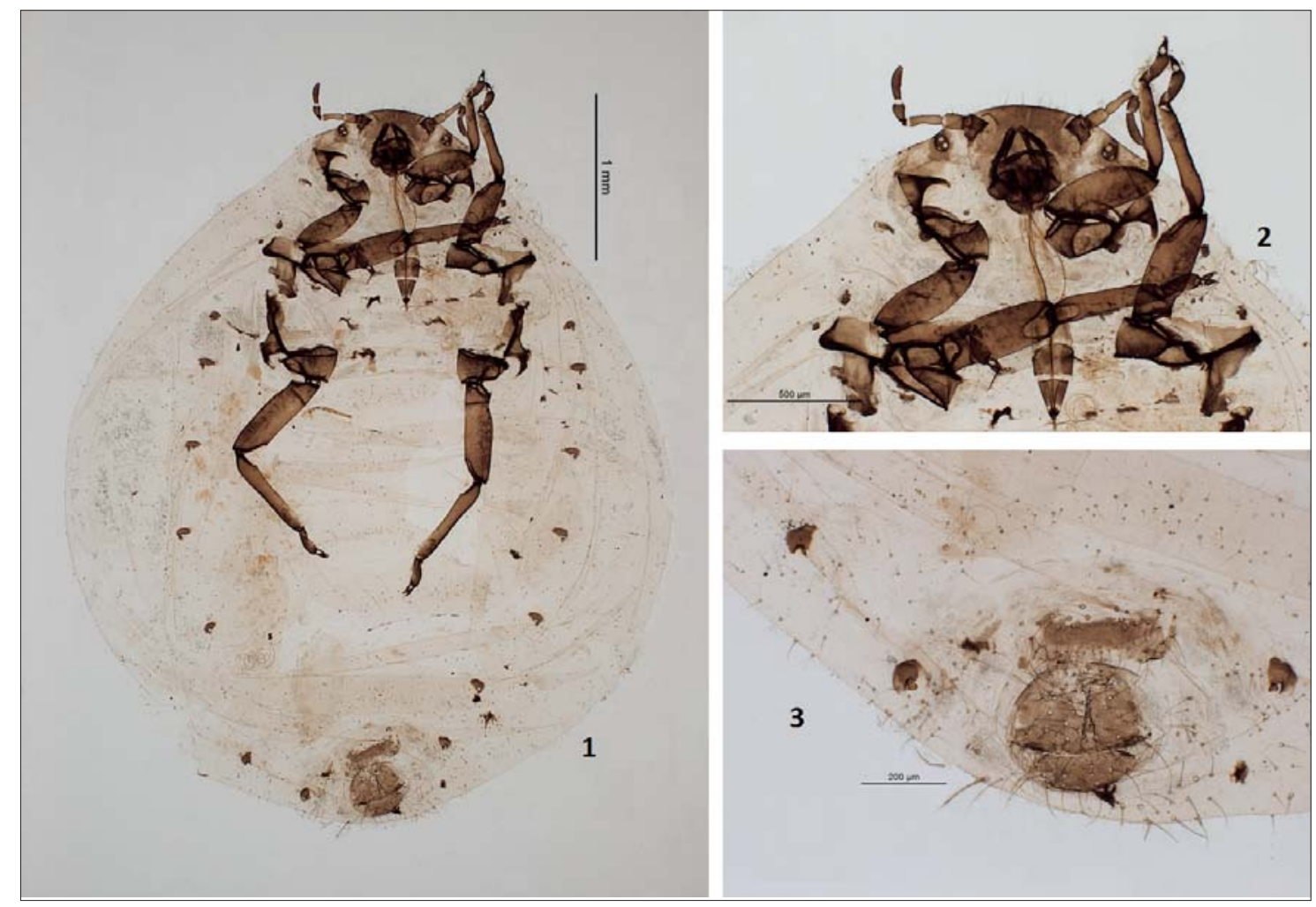

Fig. III - Fundatrix of Pachypappa warshavensis (Nasonov): habitus (1) and detail of the anterior (2) and posterior (3) part of the body. 


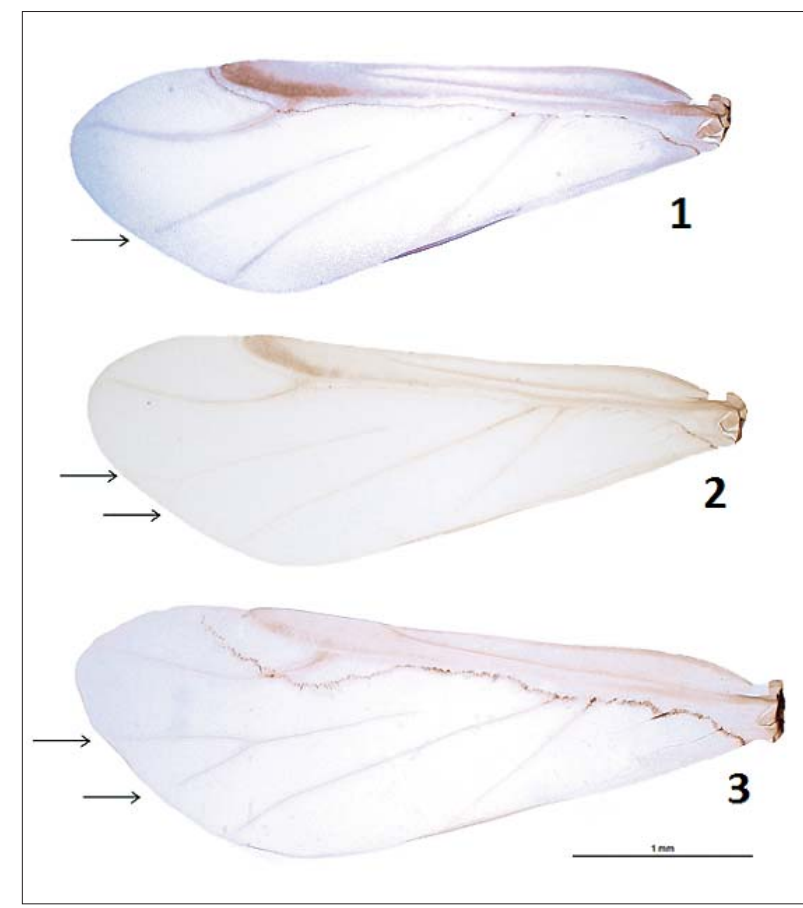

Fig. IV - Forewings of several fundatrigeniae alatae of Pachypappa warshavensis (Nasonov) with medial vein variable: unbranched (1), with a short (2) or big (3) fork (the arrows indicate the branches of the medial vein). is reddish-brown (see also http://influentialpoints.com/ Gallery/Pachypappa_aphids.htm) and in slide, they have brown head, thorax, legs, spiracular sclerites and cauda, anal and genital plates and spinal sclerotization on abdominal segments IV to VIII (Fig. V).

The antennae are $1.05-1.17 \mathrm{~mm}$, and $0.30-0.37$ times the body length (Fig. V, 1). The antennal segment III is 0.31 $0.36 \mathrm{~mm}$ and have 3 to 7 secondary sensoria located in $68 \%$ of the distal part of the segment (Fig. II, 1), the IV is 0.16$0.19 \mathrm{~mm}$ and have from 1 to 4 secondary sensoria, the $\mathrm{V}$ is $0.18-0.23 \mathrm{~mm}$ and have until 3 secondary sensoria, and the VI is $0.22-0.26 \mathrm{~mm}$ and without secondary sensoria; the terminal process is $0.13-0.20$ times the basal part of the last segment and the diameter of the primary sensoria on antennal segment VI is $0.02-0.05 \mathrm{~mm}$. The antennal segment III have 5 to 12 setae that are 1.22-2.14 times the articular diameter of the same article $(D)$. The rostrum is $0.69-0.77 \mathrm{~mm}$ and its apical rostral segment is $0.17-0.20$ $\mathrm{mm}, 1.51-2.56$ times its basal width and 0.59-0.68 times the segment of the hind tarsus; and have two accessory hairs. The siphunculi pores are very small, around 0.04-0.05 mm and 0.60-0.89 times the diameter in the middle of the hind tibia. The cauda is rounded and short (1.1-2.10 mm and 0.20-0.41 times its width) and have 16 to 20 setae, some of which are longer and thicker (Fig. V, 3). The anal plate shows a variable number of setae, from 28 to 48 , while the genital plate has around 18-27 (with 6 to 11 on anterior half), with the setae of anterior part slightly longer and

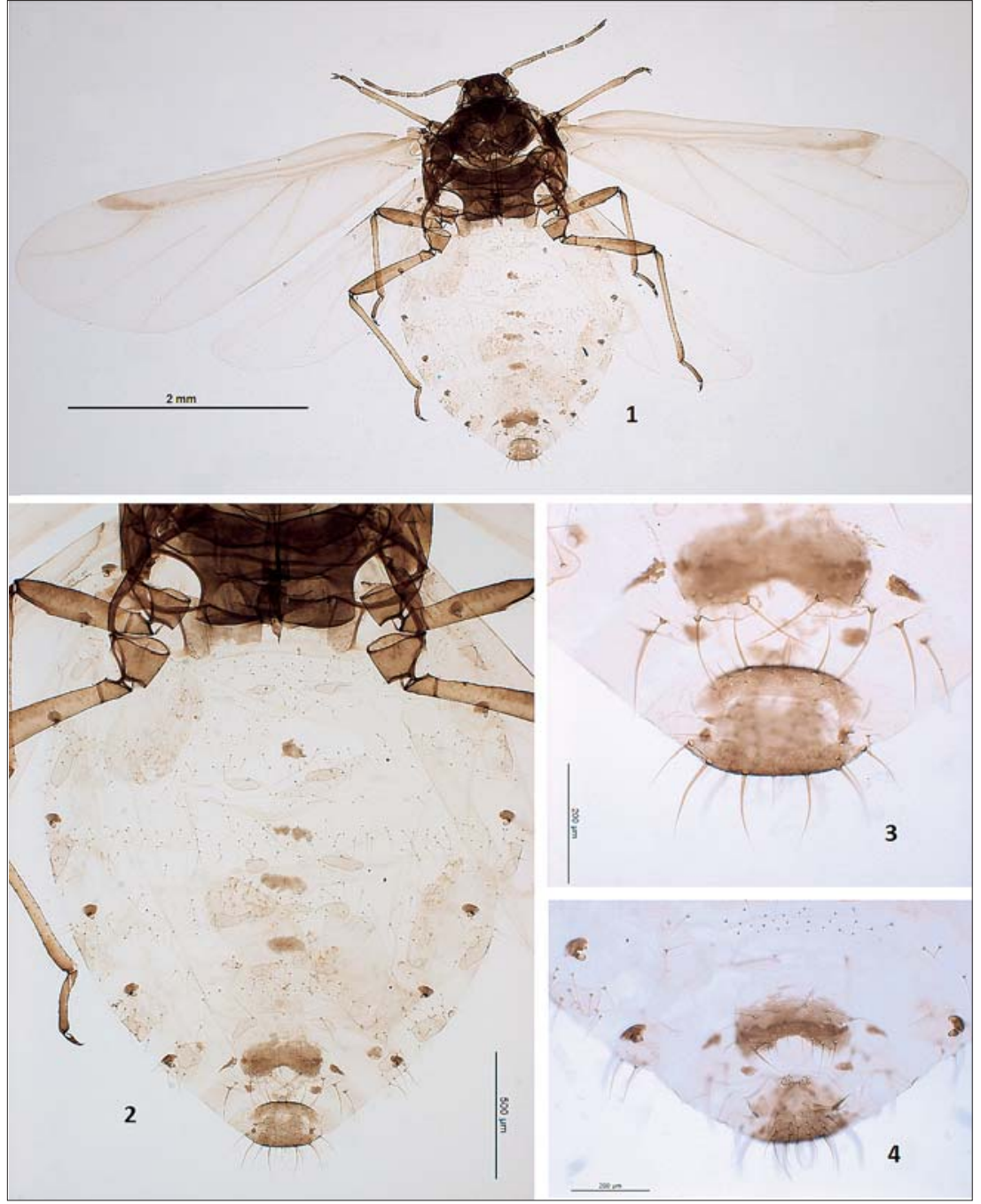

Fig. V - Fundatrigenia alata of Pachypappa warshavensis (Nasonov): habitus (1), abdomen (2) and dorsal (3) and ventral (4) view of the posterior part of the body. 
thicker (Fig. V, 4). The hind legs have femora of 0.32-0.45 $\mathrm{mm}$ and tibiae of $0.48-0.57 \mathrm{~mm}$ and $0.09-0.14$ and $0.14-$ 0.17 times the body length, respectively; and the setae of hind tibia are $0.05-0.08 \mathrm{~mm}$ and $2.00-2.35$ times $D$. Formula tarsal 2.2.2. The wax plates are absent on the head and present on the prothorax and metathorax (a spinal pair and another marginal), mesothorax (one pair spinal) and on all abdominal segments (a spinal pair on abdominal segments I to VIII and a marginal pair on the segments I to VII, that in the latter can be divided) (Fig. V, 2). The body setae are pointed and large: on frons are $0.05-0.09 \mathrm{~mm}$ (2.25-3.43 times $D)$, the spinal setae on the abdominal segment III are $0.11-0.15 \mathrm{~mm}(3.89-6.71$ times $D)$ and the marginal of the same segment are $0.10-0.13 \mathrm{~mm}(3.56-6.00$ times $D$ ), while the ventral ones are more delicate and a little shorter (0.08-0.15 $\mathrm{mm}$ and 3.25-6.25 times $D)$ and the setae on the abdominal segment VIII (4 to 10) are 0.18-0.21 $\mathrm{mm}$ and 6.67-8.71 times $D$. Nine specimens were dissected to count the embryos, finding a range between 105-269, with a mean value of 200 embryos.

\section{MOLECULAR DATA}

The phylogenetic tree including other Pachypappa species built using molecular data corresponding to a partial sequence of the mtDNA gene encoding the subunit I of the cytochrome oxidase (COI) confirmed that the specimens belong to the Pachypappa genus (Fig. VI).

\section{BIOLOGY AND DISTRIBUTION}

Pachypappa warshavensis shows mainly $P$. alba as primary host, although there are also records on $P$. canescens, P. euphratica and P. pruinosa (SHAPOSHNIKOV, 1964; CARTER and DANIELSSON, 1993) and there is a record on the Nearctic Populus tremuloides Michx. (PoljakovićPAJNIK, 2006) in Serbia, that must be confirmed. According to SzELEgIEWICZ (1982), apterae recorded on roots of Salix caprea L. could be assigned to this species. Also, CARTER and Danielsson (1993) tentatively associate $P$. warshavensis to adult apterae and alatoid nymphs found around roots of Populus canescens in Wales (in October) and on fine roots in England (in June), but these both relations need experimental transfers and molecular studies.

Pachypappa warshavensis is a Palaearctic species that is widely distributed in Europe (Belarus, Germany, Hungary, Poland, Romania, Serbia, Sweden and Ukraine) and more recently was recorded in Central Asia (Kazakhstan) (Holman, 2009; KadyrbeKov, 2011). Several authors (Gómez-Menor and Nieto, 1977) and later Heie (1980) mentioned $P$. warshavensis in Spain but PÉREZ HIDALGO and NiETo NAFría $(2003 \mathrm{a}, \mathrm{b})$ not included this species in the review of the Iberian Eriosomatinae because they did not find specimens to corroborate this record in any aphidological collection. Our record confirms the presence of this species in the Northwest of Spain (province of León) and allows us to think that it is also present in the province of Madrid according GóMEZ-MENOR and NIETO (1977).

\section{DISCUSSION}

The species of genus Pachypappa present complex cycles with up to six very different morphs (fundatrix, fundatrigenia alata, virginogenia aptera, sexupara, ovipara and male). As a result, not all morphs have been correctly described for every species and some of them are not even known (PIKE et al., 2011; BlACKMAN and EASTOP, 2019). In the case of $P$. warshavensis there are descriptions of fundatrix and fundatrigenia alata (HEIE, 1980) made with few specimens and characters (SZELEGIEWICZ, 1982), which sometimes generates problems when identifying the known forms of the different species.

Our morphological identification was carried out using the keys for fundatrix of HeIE (1980) and the keys to identify alatae of HeIE (1980) and BLACKMAN and EASTOP (2019). In these last keys, they use the medial vein parameter (once-branched or unbranched vein) to separate the genus Gootiella Tullgren and to discriminate Pachypappa at a specific level. In particular, the last operation results problematic, because the polymorphism of the medial vein (Fig. V), which can have a big branch, a small branch or be unbranched and also because every individual can show different polymorphism at the same time, one on each forewing (see description of fundatrigenia alata).

Also in the identification, we even considered the description of $P$. warshavensis of HEIE (1980) and we

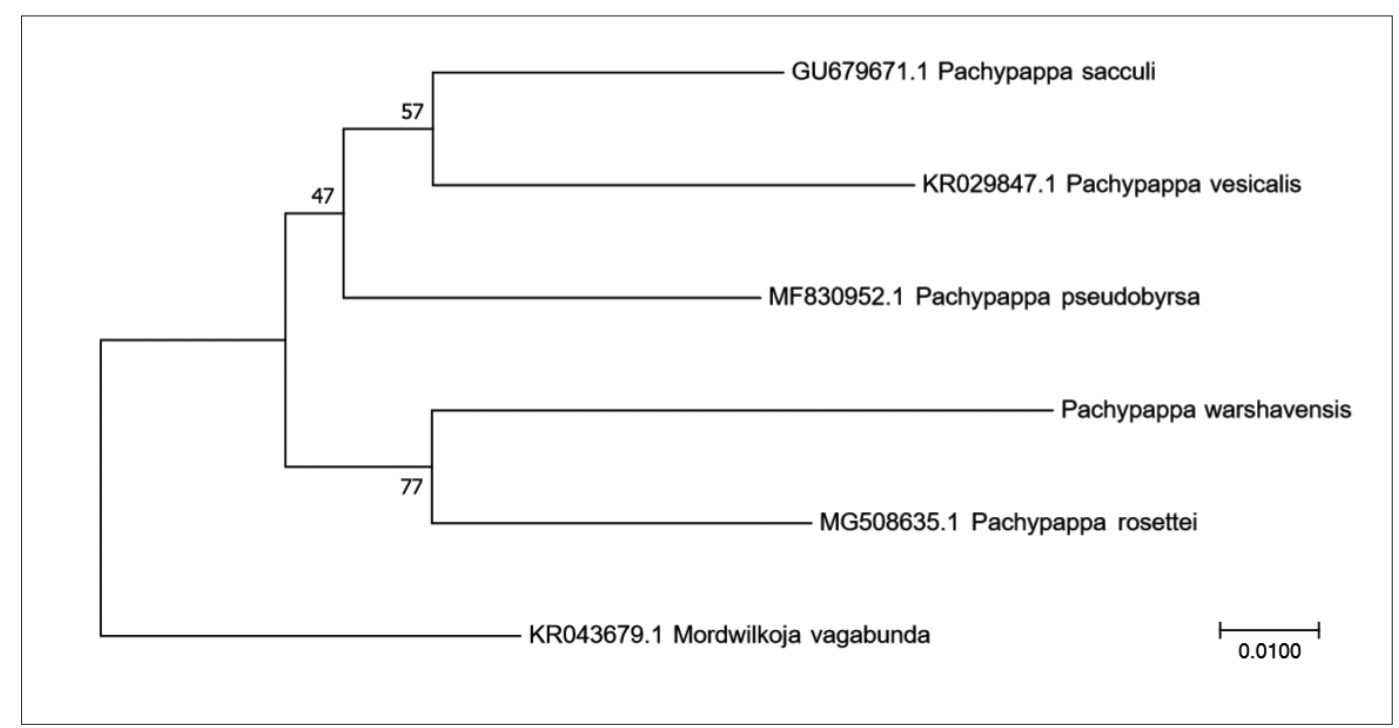

Fig. VI - Neighbour-joining phylogenetic tree (COI) from sequences of species of Pachypappa. 
noticed that our fundatrix is slightly bigger $(4.34 \mathrm{~mm})$ than the fundatrix presented by him $(4 \mathrm{~mm})$. But, in any case, the number of the hairs can clearly separate the fundatrix of $P$. warshavensis (Fig. II) of the fundatrix of $P$. tremulae (see figure A in plate 1 in StroYAn, 1975).

Other problems showed up with the molecular analysis because sequences of Pachypappa warshavensis are not present in NCBI and we did not find specific matches using BLAST.

Although the species of the subfamily Eriosomatinae are among the first species of aphids mentioned in the Iberian Peninsula (PÉrez Hidalgo and Nieto Nafría, 2003b), some of them are difficult to locate although they live on very abundant and frequent plants, such as different species of Populus, or because they form colonies in roots of their secondary hosts.

Currently, the lack of aphidologists and faunistic studies means that there are large gaps in the known distribution of many species. However, the recent fondness for photography has helped in meeting and citing some species of aphids, apparently scarce, by naturalists or photography enthusiasts, as is the case of Plocamaphis flocculosa (Weed) a boreal species detected recently in the Iberian Peninsula (PÉrez Hidalgo et al., 2016).

The known distribution of Pachypappa species and their chorology suggested aphidologists that their presence in territories of the Iberian Peninsula was unlikely since they were assumed to be boreal species (PÉrez HidAlgo and NieTo NAFría, 2003a).

Pachypappa warshavensis is widely distributed in Europe on Populus alba and probably also in the Iberian Peninsula. For this reason, we consider appropriate and useful the contribution that citizen science can give (WHEELER and VALDECASAS, 2010). Allowing naturalists to search and document the presence of organisms and interacting with experts to obtain information without excessive effort, may thus establish a beneficial symbiosis for all players in this game of knowledge enrichment (HAND, 2010; GURA, 2013).

Pachypappa species are recorded as important pests for both deciduous (as Populus) or evergreen (as Picea) forest trees (BARJADZE and JAPOSHVILI 2007). In particular, spruces can suffer from aphids attacks: for example, damages to spruce seedlings, some very severe, have been documented in nurseries in Canada (LAVALLÉE, 1987). Targeted plants appear severely affected, with gradually yellowing of needles and sometimes even needles falling. The genus can even affect the Norway spruce, grown for Christmas market (AlForD, 1991). In Europe, Pachypappa vesicalis is considered as pest (WATT et al., 1997) and its presence is well established in spruce plantations in Britain, on trees of all ages (CARTER and DANIELSSON, 1991). P. warshavensis is recorded as pest of aspen with $P$. marsupialis in Georgian urban habitats (BARJADZE and JAPOSHVILI, 2007), but the commercial interest in Populus spp. is not relevant.

At the moment the genus Pachypappa is under control and causes very little damage (SUTHERLAND and VAN EERDEN, 1980; WONG, 1982; EL-SAYED, 2019) but we lack information about this aphid group as disease vector for plants and at the same time we know little about its natural predators and pathogens that can be used in its biological control. Experiments were carried out only for another species of Pemphigini, for example, Pemphigus betae Doane, and never with Pachypappa (LAVALLÉE, 1987; SWAN and PAPP, 1972; HARPER, 1961). More investigations are required to understand the possible risks for the agroforest business.

\section{ACKNOWLEDGEMENTS}

The authors are very grateful to the reviewers of the manuscript, to Barbara Osiadacz (Poznań University of Life Sciences, Poznań, Poland) and Andrey Stekolshchikov (Zoological Institute of Russian Academy of Science, Saint Petersburg, Russia) for facilitating the publications of N.V. Nasonov, A. Mordvilko and H. Szelegiewicz about Pachypappa warshavensis and to Francesca Maria Gatti (Civica Scuola Interpreti e Traduttori Altiero Spinelli, Milan, Italy) for the translation of articles in Russian. The investigation was conducted in the context of Project CGL2015-68188-P, funded by "Ministerio de Economia, Industria y Competitividad" of Spain (MIMECO).

\section{REFERENCES}

Alford D.V., 1991 - Pests of Ornamental Trees, Shrubs and Flowers. Wolfe Publishing Ltd, London, 480 pp.

BARJADZE SH., JAPOSHVILI G., 2007 - Aphid insect pests on ornamental plants in urban habitats in Georgia. Caucasian Entomol. Bull., 3(2): 235-245.

BLACKMAN R.L., EASTOP V.F., 2019 - Aphids on World's plants. An online identification and information guide. Available from http://www.aphidsonworldsplants.info (accessed 27 February 2019).

CARTer, C.I., Danielsson, R., 1991 - Two spruce root aphids, Pachypappa vesicalis and Pachypapella lactea new to Britain with illustrated keys to the morphs from Picea roots. - Entomologist, 110: 66-74.

CARTER C.I., DANIELSSON R., 1993 - New and additional records of gall-forming aphids of the family Pemphigidae in Britain. - Entomologist, 112: 99-104.

El-Sayed A.M., 2019 - The Pherobase: Database of Pheromones and Semiochemicals. - Available from: www.pherobase.com (accessed 4 March 2019).

FAVRET C., 2019 - Aphids species file. Version 5.0/5.0. Available from: http://aphid.speciesfile.org (accessed 27 February 2019).

Folmer O., Black M., Hoeh W., Lutz R., VRijenhoek R., 1994 - DNA primers for amplification of mitochondrial cytochrome c oxidase subunit I from diverse metazoan invertebrates. - Mol. Mar. Biol. Biotech., 3(5): 294-299.

Gómez-Menor J., Nieto J.M., 1977 - Contribución al conocimiento de los pulgones de España (Hem. Homoptera Aphidoidea). - Graellsia, 32: 227-260.

GURA T., 2013 - Citizen science: amateur experts. - Nature, 496(7444): 259-261. doi:10.1038/nj7444-259a.

Hand E., 2010 - Citizen science: People power. - Nature, 466(7307): 685-687. doi:10.1038/466685a

HARPER A.M., 1961 - Effect of insecticides on the sugar beet root aphid, Pemphigus betae. - J. Econ. Entomol., 54(6): 1151-1153.

HeIE O.E., 1980 - The Aphidoidea (Hemiptera) of Fennoscandia and Denmark. I General Part. The Families Mindaridae, Hormaphidae, Thelaxidae, Anoeciidae, and Pemphigidae. - Fauna entomol. Scand., 9: 1-236.

Holman J., 2009 - Host plant catalog of aphids. Palaearctic Region. Springer Science+Business Media B.V., 1216 pp.

KADYRBEKOV R.KH., 2011 - About fauna of aphids (Homoptera, Aphididae) of the gallery forests of Syrdariya river. - Vestnik KazNU, 1(47): 65-73.

Kumar S., Stecher, G., Tamura, K., 2016 - MEGA7: molecular evolutionary genetics analysis version 7.0 for bigger datasets - Mol. Biol. Evol., 33(7): 1870-1874.

LAVALlÉE R., 1987 - Bibliographical review of Pachypappa 
tremulae $(L)$ : a root aphid of conifer seedlings in containers. - Laurentian Forestry Centre, Canada, Information Report LAU-X-73E, 16 pp.

Nieto Nafría J.M, Andreev A.V, Binazzi A, Mier Durante M.P, Pérez Hidalgo N., Rakauskas R., Stekolshchikov A.V., 2011 - Fauna Europaea: Aphidoidea. Fauna Europaea, version 2017.06. http://www.faunaeur.org

Nieto Nafría J.M., Mier Durante M.P., 1998 Hemiptera, Aphididae I. In: Ramos M.A. et al. (Eds.) Fauna Ibérica Volumen 11. - Museo Nacional de Ciencias Naturales, C.S.I.C, Madrid, 424 pp.

PÉrez Hidalgo N., Nieto NAfría J.M., 2003a - Check-list of Eriosomatinae (Hemiptera, Sternorrhyncha: Aphididae) of the Iberian Peninsula and Balearic Islands. - Acta Entomol. Ib. e Mac., 1: 67-73.

Pérez Hidalgo N., Nieto NAfría J.M., 2003b - Subfamilia Eriosomatinae Kirkaldy, 1905 (1843). In: Hemiptera, Aphididae II. Nieto Nafría et al. In: Ramos M.A. et al. (Eds.) Fauna Ibérica, vol. 19. Museo Nacional de Ciencias Naturales, CSIC, Madrid [2002], pp. 141-275.

Pérez Hidalgo, N., Sanmartín M., Nieto Nafría J.M., 2016 - Primera cita de Plocamaphis flocculosa (Weed, 1891) (Hemiptera: Aphididae: Aphidinae: Macrosiphini) en la Península Ibérica. - Arq. Entomol., 15: 25-28.

Pike K., Graf G., Foottit R., Maw H., Von Dohlen C., Harpel J., Hagerty A., 2012 - Eriosomatine aphids (Hemiptera: Aphididae: Eriosomatinae) associated with moss and roots of conifer and willow in forests of the Pacific Northwest of North America. - Can. Entomol., 144: 555-576.

PolJAKOVIĆ-PAJNIK L., 2006 - Pachypappa warshavensis (Aphididae: Homoptera) nova vrsta biljne vaši na belim topolama u Srbiji. - Topola, 177-178: 138-142.

Shaposhnikov G.KH., 1964 - Suborder Aphidineae, Plant Lice. In: Bei Bienko, G.Ya. (Ed.) Keys to the Insects of European USSR. Vo. I. English Version. Israel Program Scientific Translations, Jerusalem, pp. 616-799.
Staden R., Beal K.F., Bonfield J.K., 1998 - The Staden Package. Computer Methods in Molecular Biology Volume 132. In: Bioinformatics Methods and Protocols, Misener S, Krawetz SA (Eds) The Humana Press Inc., Totowa, NJ, 115-130.

StROYAN H.L.G., 1975 - The life cycle and generic position of Aphis tremulae L., 1761 (Aphidoidea: Pemphiginae), with a description of the viviparous morphs and a discussion of spruce root aphids in the British Isles. Biol. J. Linn. Soc., 7: 45-72 (+ 2 plates and 1 figure).

Sutherland J.R., Van Eerden E., 1980 - Diseases and insect pests in British Columbia forest nurseries. - B.C. Minist. For. Cano For. Sery. Joint Report No. 12: 55.

SWAN L.A., PAPP, C.S., 1972 - The common insects of North America. Harper and Row. New York, 750 pp.

Szelegiewicz H., 1982 - Aphidological Notes. $V-X$. (Homoptera, Aphidoidea). - Ann. Zool., 18 (36): $363-$ 374.

TAmura K., Dudley J., Nei M., Kumar S., 2007 - MEGA4: Molecular Evolutionary Genetics Analysis (MEGA) software version 4.0. - Mol. Biol. Evol., 24: 1596-1599.

Thompson J.D, Gibson T.J., Plewniak F., Jeanmougin F., HigGINS D.G., 1997 - The ClustalX windows interface: flexible strategies for multiple sequence alignment aided by quality analysis tools. - Nucleic Acids. Res., 25: 48764882.

Truett A.A., Walker J.A., Warman M.L., Truett G.E., Heeger P., Mynatt R.L., 2000 - Preparation of PCRquality mouse genomic DNA with Hot Sodium Hydroxide and Tris (HotSHOT). - BioTechniques, 29(1): 52-53.

WATt A.D., HunTER M., StORK N.E. (eds), 1997 - Forests and Insects. Chapman and Hall, London. 196 pp.

Wheeler Q., Valdecasas A.G., 2010 - Cybertaxonomy and Ecology. - Nat. Educ. Know., 3(10): 6.

Wong H.R, 1982 - Some insect pests of forest tree nurseries in the canadian prairies. - For. Manage. Note 15: 45. 
120 - Blank Page 